\title{
STRATEGI PEMASARAN PT. TWC DALAM MENINGKATKAN KUNJUNGAN WISATAWAN DAN LABA USAHA PENGELOLAAN CANDI BOROBUDUR, PRAMBANAN DAN RATU BOKO
}

\author{
Atun Yulianto \\ Akademi Pariwisata "BSI Yogyakarta" \\ E-mail : atun.aty@bsi.ac.id
}

\begin{abstract}
PT. Taman Wisata Candi (TWC) is a form of concern the government to maintain and preserve the cultural and historical heritage in the form of temples Borobudur, Prambanan\&RatuBoko palace. As a profit-oriented Limited Liability Company, evaluation is needed to measure the performance of the company as part of accountability to stakeholders. In this paper the subject focuses on the analysis of the implementation of the company's marketing strategy in increasing the number of visits and business profit. Therefore, the research method used is descriptive qualitative backed quantitative data. The results showed that marketing st rategy of 'low cost high impact' applied by the company in 2014 through increased penetration of the domestic market, foreign market development, increase awareness of domestic market, development of services and creation of new tourism products resulted in an increase in the number of visitors $2.8 \%$ and operating profit $10.4 \%$ from the previous year. While cost efficiency (low cost) in 2014 yet to show maximum results, because the increase in the cost of direct as big as $45,9 \%$ is not significant with the company's operating profit increase as big as $10.4 \%$. In this case the increase in direct operating costs is greater rather than increase in the amount of corporation profits and followed by a decrease in the liquidity of the company with the current ratio is smaller than the previous year.
\end{abstract}

Keywords: Marketing strategy, Operating profit, Visitor

\section{PENDAHULUAN}

Saat ini sektor pariwisata telah berkembang menjadi salah satu industri yang mampu mendatangkan devisa bagi suatu negara. Cepatnya pertumbuhan sektor pariwisata ini memunculkan berbagai manfaat baik bagi negara maupun masyarakat yang berada pada area destinasi. Keadaan ini dapat diartikan bahwa sektor pariwisata telah mampu menggerakkan perekonomi mulai dari lingkup masyarakat bawah sampai dengan pemerintahan. Pariwisata telah menjadi pemicu kegiatan ekonomi yang sangat penting bagi suatu wilayah destinasi, karena dari sektor pariwisata ini dimungkinkan terciptanya lapangan kerja yang luas mulai dari industri perhotelan, travel \& tour sampai dengan penjualan souvenir daerah. Pembangunan sektor pariwisata yang berkelanjutan dibutuhkan untuk meningkatkan kualitas jasa pariwisata yang dijual, sehingga dapat meningkatkan jumlah kunjungan dan devisa bagi negara.

Yogayakarta merupakan salah satu dari sekian banyak destinasi pariwisata Indonesia selain Bali. Potensi wisata yang dimiliki Yogyakarta terbentuk dari kondisi geografis, sejarah dan budaya yang dimilikinya. Jumlah wisatawan domestik maupun asing yang berkunjung dan menginap ke kota ini dalam tiga tahun terakhir terus mengalami peningkatan. Selama tahun 2013, jumlah wisatawan yang berkunjung ke DIY mencapai 3,81 juta, terdiri dari 3,60 juta wisatawan domestik dan 207,28 ribu wisatawan asing. Jumlah wisatawan domestik jauh lebih dominan dibanding wisatawan asing dengan porsi sekitar 94,56 persen (BPS DIY 2014).

Keberadaan wisatawan asing ini memberikan kontribusi yang baik terhadap 
sektor ekonomi khususnya melalui penukaran mata uang asing. Meningkatnya pertumbuhan jumlah wisatawan ke Yogyakarta selama tiga tahun terakhir secara langsung maupun tidak langsung menyebabkan naiknya pendapatan sektor rumah tangga dan pemerintah daerah, sehingga memicu kebijakan pemerintah dalam mempromosikan pariwisata ke negara lain.

Dengan gencarnya promosi pariwisata ini diharapakan menjadi awal bangkitnya pertumbuhan ekonomi disuatu wilayah. Indikator pertumbuhan ekonomi salah satunya adalah perkembangan jumlah usaha akomodasi dimasyarakat. Usaha akomodasi di Yogyakarta dipertengahan tahun 2015 mengalami peningkatan sebesar 19,72 persen dibandingkan tahun 2014. Pertumbuhan jumlah hotel dan akomodasi lainnya yang tersebar di beberapa wilayah berjumlah 1.166 ditahun 2015, kenaikan ini terlihat dari jumlah usaha yang sama dari tahun sebelumnya sebesar 1.138. Pariwisata di Yogyakarta selain dibentuk oleh kondisi geografis, terdapat potensi lain yang dapat diunggulkan khususnya pada bidang sejarah dan budaya.

Banyaknya peninggalan sejarah dan budaya di kota Yogyakarta membutuhkan komitmen pemerintah untuk melestarikannya. Satu diantara sekian banyak peninggalan sejarah yang ada adalah candi. Candi di Yogyakarta berjumlah ratusan sehingga membutuhkan penanganan yang profesional untuk dapat menjadi daya tarik wisata. Dari sekian banyak candi yang dikelola secara profesional untuk daya tarik wisata adalah candi Borobudur, Prambanan dan Ratu Boko. Ketiganya dikelola oleh perusahaan yang dibentuk pemerintah dengan nama PT. Taman Wisata candi sebagai wujud kepedulian pemerintah terhadap upaya menjaga dan melestarikan warian budaya dan sejarah ini. Dengan kenaikan jumlah kunjungan wisatawan domestik dan mancanegara ke Yogyakarta secara langsung dan tidak langsung berdampak positif terhadap jumlah kunjungan ke tiga candi yang dikelola PT. Taman Wisata Candi. Kedatangan wisatawan ini juga memberikan dampak positif terhadap pendapatan asli daerah (PAD), dimana penerimaan ini bersumber dari pajak daerah, retribusi daerah, bagian laba BUMD, penerimaan dari dinas-dinas, dan penerimaan lain- lain.

Keberhasilan PT. Taman Wisata Candi memilih strategi pemasaran khususnya dalam menaikkan jumlah kunjungan wisatawan ke Yogyakarta tercermin dari keberhasilan perusahaan mendatangkan pengunjung maupun kinerja keuangannya. Optimalisasi strategi pemasaran yang diimplementasikan perusahaan tiga tahun terakhir menunjukkan peningkatan dalam jumlah kunjungan wisatawan secara komulatif yaitu sebanyak 5.255.109 orang ditahun 2014 naik 290.673 orang dari tahun 2013, sehingga berdampak pada kenaikan laba usaha sebesar Rp. 42.808 miliar di tahun 2014 dibanding tahun 2013 yang sebesar Rp. 34.728 miliar. Namun demikian terdapat satu keadaan dimana terjadi penurunan pertumbuhan asset ditahun 2014 sebesar 18,1\% dibanding tahun 2013 $(21,2 \%)$ yang diikuti juga dengan kenaikan biaya operasi perusahaan. Sementara itu terdapat kondisi sebaliknya pada pos pasiva yang mengalami perbaikan dengan turunnya jumlah pertumbuhan hutang perusahaan ditahun 2014 sebesar 7,9\% dibanding tahun 2013 sebesar 63,9\% (Annual Report PT. TWC, 2014). Berdasarakan data dan fakta tersebut, peneliti tertarik untuk membuat sebuah analisis kualitatif dengan tujuan untuk mengetahui keberhasilan implementasi strategi pemasaran PT. Taman Wisata Candi (TWC) dalam mendatangkan pengunjung dan keuntungan bagi perusahaan.

\section{LANDASAN TEORI}

\section{Wisata Candi}

Candi adalah bangunan keagamaan 
yang didirikan ratusan tahun yang lalu (Dumarcay, 2007). Candi-candi yang diciptakan oleh para leluhur berisi pesan dalam bentuk arsitektur, relief, serta patungpatung yang tak lepas dari unsur-unsur spiritualitas, daya cipta dan keterampilan pemahatnya (Wendoris,2008:7). Candi warisan budaya nusantara sangat banyak dijumpai hampir diberbagai wilayah di Indonesia, khususnya pulau jawa. Candicandi banyak ditemukan dipulau jawa karena pulau jawa khususnya bagian barat telah menjadi jalur perdagangan dunia dan merupakan penghasil rempah-rempah yang sangat diminati oleh para pedagang yang berasal dari negara-negara lain. Dari sinilah para penguasa saat itu berhubungan dengan berbagai budaya asing yang membawa dampak pada kepercayaan masyarakat saat itu

Saat ini sudah dianggap lazim bahwa bangunan candi yang ada di Indonesia merupakan salah satu destinasi pariwisata. Banggunan candi ini menjadi aset wisata daerah yang diminati banyak wisatawan. Wisatawan tertarik akan keunikan bangunan baik dari susunan batu, seni pahat, patung, relief, cerita dan keindahannnya. Sebagai dstinasi wisata kini taman wisata candi dikelo secara profesional oleh sejumlah BUMN. PT. Taman Wisata Candi (TWC) menjadi salah satu perusahaan yang secara profesional mengelola tempat wisata candi untuk mendatangkan sebanyak mungkin wisatawan domestik dan mancanegara dengan tujuan profit yang mendukung pembangunan daerah.

\section{Kinerja Perusahaan}

Hasil kerja suatu orgaisasi tidak akan dapat diketahui nilainya tanpa adanya evaluasi kinerja dengan indikator tertentu sebagai ukuran. Kinerja yang baik dibutuhkan untuk tercapainya tujuan organisasi. Dibutuhkan komitmen manajemen dan karyawan agar pekerjaan yang dilakukan menghasilkan output yang mendorong tercapainya kinerja perusahaan. Penilaian kinerja perusahaan adalah pengukuran hasil kerja baik manajemen maupun setiap bagian perusahaan. Penilaian kinerja adalah penentuan secara periodik efektivitas operasional suatu organisasi, bagian organisasi dan karyawannya (Rudianto, 2005:337).

Tolok ukur atau standar kinerja yang baku dapat dijadikan sebagai panduan agar penyimpangan yang mungkin terjadi dari aktifitas kerja suatu organisasi dapat dihindarkan. Standar kinerja diperlukan untuk memacu organisasi agar bekerja sesuai dengan sasaran yang telah ditetapkan sehingga tujuan organisasi dapat tercapai. Menurut keputusan Kepala LAN No.239/ IX/6/8/2003 tentang panduan pengukuran kinerja instansi pemerintah menjelaskan beberapa tahap yaitu tahapan penetapan kinerja, pengumpulan data kinerja dan cara pengukuran kinerja. Pengukuran kinerja dilakukan dengan indikator input, output, outcame, benefit dan impact. Semua indikator tersebut diperlukan tiap periode atau akhir tahun untuk mengukur kehematan, efisiensi, efektifitas, mutu pencapaian sasaran, dan pencapaian tujuan instansi pemerintah (Rai, 2008:16).

\section{Strategi Pemasaran Industri Pariwisata}

Setiap perusahaan memiliki tujuan yang hendak dicapai untuk tetap eksis menjaga kelangsungan hidupnya. Tujuan perusahaan komersial yang paling utama adalah memperoleh laba dari pendapatan usahanya. Tujuan perusahaan dapat dicapai dengan berbagai upaya salah satunya dengan merancang strategi pemasaran yang baik. PT. Taman Wisata Candi (TWC) adalah perusahaan yang bergerak pada sektor jasa khususnya pariwisata. Jasa yang dihasilkan PT. TWC pada dasarnya merupakan semua aktifitas ekonomi yang berbentuk kenyamanan, keindahan, hiburan dan kesenangan dari objek wisata taman serta bangunan arsitek candi. Jasa menurut 
Lupiyoadi dan Hamdani (2008:6), adalah "bukan suatu barang, melainkan suatu proses atau aktifitas yang tidak berwujud".

Dalam memasarkan jasa, perusahaan membutuhkan strategi yang tepat sehingga jasa dapat terdistribusikan kepada pasar sesuai segmen yang dituju. Strategi adalah rencana fundamental untuk menetapkan arah keseluruhan dari bisnis guna mencapai tujuan perusahaan (Alma, 2011:200). Menurut Alex D. Triyana (1985) dalam Alma (2011:200-201), menjelaskan bahwa dalam menyusun strategi pemassaran terdapat dua variabel yang harus diperhatikan manajemen perusahaan yaitu variabel yang dapat dikontrol dan tidak dapat dikontrol. Variabel yang tidak dapat dikontrol meliputi (a) Keadaan persaingan, (b) Perkembangan tehnologi, (c) Perubahan demografik, (d) Kebijakan politik dan ekonomi, dan (e) Sumberdaya alam. Sedangkan variabel yang dapat dikontrol langsung meliputi (a) Segmentasi pasar, (b) Bauran pemasaran, (c) Anggaran pemasaran, (d) Kondisi waktu (timing).

Strategi pemasaran modern lebih mengutamakan pada kepuasan dan loyalitas pelanggan. Merealisasikan hal tersebut dibutuhkan perencanaan strategis dalam merumuskan strategi pemasaran yang baik. Alma (2011:258) menyimpulkan bahwa strategi pemasaran adalah strategi yang sangat mengutamakan atau berorientasi pada konsumen dengan memberikan kepuasan tertinggi dan focus pada tampilan lembaga dalam melayani konsumen dan ini berbeda dengan pemasaran tradisional yang lebih mengutamakan peningkatan volume penjualan. Pada industri jasa pariwisata strategi pemasaran difocuskan pada pengelolan jasa pariwisata yang berorientasi pada kepuasan wisatawan sehingga memiliki loyalitas untuk kembali berkunjung dan menyampaikan informasi pengalamannya kepada orang lain. Pada tulisan ini analisis strategi pemasaran lebih fokus pada data yang sifatnya terukur secara kuantitatif (pemasaran tradisional) yaitu beorientasi pada jumlah kunjungan wisatawan dan pertumbuhan keuangan perusahaan.

\section{METODE PENELITIAN}

Penelitian ini memusatkan perhatian pada masalah implementasi strategi pemasaran yang diterapkan PT. Taman Wisata Candi dalam upaya meningkatkan jummlah kunjungan dan keuntungan perusahaan. Penelitian ini berusaha untuk mendapatkan gambaran yang jelas suatu gejala atau peristiwa yang terjadi pada periode tertentu secara natural sehingga metode penelitian yang digunakan adalah diskriptif kualitatif. Guna menganalisis implementasi strategi pemasaran perusahaan pada kondisi yang alamiah (natural setting), maka metode pengambilan data yang digunakan adalah dengan pengamatan, dokumentasi, penelusuran dan study pustaka.

\section{HASIL DAN PEMBAHASAN}

PT. Taman Wisata Candi (TWC) merupakan perusahaan BUMN yang didirikan pemerintah sejak tahun 1980an. Kegiatan utama perusahaan adalah melakukan usaha dibidang pengusahaan lingkungan Candi Borobudur, Candi Prambanan dan Candi Ratu Boko serta peninggalan sejarah dan purbakala lainnya sebagai suatu Taman Wisata dan Usaha di bidang pariwisata lainnya, serta optimalisasi pemanfaatan sumber daya yang dimiliki Perseroan untuk menghasilkan barang dan jasa bermutu tinggi dan berdaya saing kuat untuk mengejar keuntungan guna meningkatkan nilai Perseroan dengan menerapkan prinsip-prinsip Perseroan Terbatas. Hal tersebut sesuai dengan salah satu misi perusahaan yaitu meningkatkan nilai Perusahaan secara berkelanjutan. Meningkatkan nilai perusahaan yang berkelanjutan membutuhkan kerjasama semua bagian dalam perusahaan untuk menghasilkan jasa dibidang pariwisata yang mampu mendatangkan sebanyak 
mungkin pengunjung sehingga berimbas pada peningkatan keuntungan dan nilai perusahaan.

Penerapan strategi pemasaran yang tepat menjadi bagian terpenting dalam mengelola perusahaan dalam rangka mendatangkan pengunjung untuk meningkatkan arus kas masuk perusahaan. Selama tahun 2014 menajemen PT. TWC menetapkan strategi pemasaran dengan konsentrasi pada strategi low cost hight impact. Strategi tersebut merupakan strategi pemasaran yang menitikberatkan pada efisienasi biaya namun tetap memberikan dampak besar terhadap kinerja perusahaan. Strategi ini memerlukan pemilihan program yang tepat berdasarkan target pasar yang ada. Secara garis besar, kebijakan pemasaran ditujukan untuk mempertahankan tingkat kunjungan wisatawan dari pasar konvensional sambil melakukan penetrasi kepada pasar-pasar potensial. Selain hal tersebut, langkahlangkah sinergis bekerjasama dengan berbagai pihak dilakukan dalam rangka pelaksanaan pemasaran dan promosi bersama selama 2014. Beberapa diantaranya melalui kerjasama dengan Kementerian Pendidikan dan Kebudayaan, Kedutaan Besar, serta pelaku-pelaku pariwisata baik nasional maupun internasional.

\section{Kinerja Perusahaan}

Kinerja perusahaan diukur berdasarkan beberapa indikator antara lain capaian laba periodik yang dihasilkan perusahaan dari hasil penjualan. Pada tahun 2014 penerapan strategi pemasaran PT. TWC dalam mencapai kinerja yang baik tidak lepas dari kendala beberapa faktor eksternal, antara lain sebagai berikut :

a. Faktor alam

Faktor alam menjadi salah satu faktor yang mempengaruhi kinerja perusahaan secara keseluruhan. Faktor alam tidak dapat dicegah sehingga memerlukan strategi antisipasi agar strategi pemasaran perusahaan tetap berjalan sesuai yang direncanakan. Faktor alam seperti bencana gunung meletus, gempa bumi, serta kebakaran merupakan faktor yang menyebabkan strategi pemasaran sering kali berubah dan tidak dapat dijalankan sehingga target perusahaan dimungkinkan tidak dapat dicapai.

b. Faktor makro

Faktor makro seringkali menjadi pemicu naik- turunnya kinerja perusahaan. Kondisi perekono- mian global yang tidak stabil menjadi faktor makro yang berdampak kepada pertumbuhan industri pariwisata sehingga mempengaruhi jumlah kunjungan dan berpengaruh langsung kepada pejualan perusahaan.

c. Faktor yang sifatnya klasik

Faktor klasik seperti keterbatasan infrastruktur dan konektivitas terutama bandar udara masih menjadi kendala dalam pencapaian salah satu target utama perusahaan yaitu peningkatan market share wisatawan manca Negara.

Dengan berbagai hambatan yang ada perusahaan berupaya maksimal untuk meningkatkan kinerjanya selama tahun 2014. Manajemen melaksanakan aktivitas operasional perusahaan dengan menerapkan prinsip-prinsip pengelolaan perusahaan yang baik (good corporate governance) melalui berbagai aturan tata tertib (code of conduct) yang dijadikan sebagai dasar rujukan bagi masing-masing personil dalam bertindak melaksanaan tugas. Menjaga berbagai aturan (code of conduct) perusahaan untuk meraih kinerja yang baik membutuhkan komitmen seluruh personil sehingga perusahaan menerapkan sistem pelaporan pelanggaran (whistleblowing system) yang memungkinkan setiap orang untuk melaporkan adanya dugaan kecurangan, pelanggaran hukum dan etika serta misconduct lainnya sesuai dengan asas dan regulasi yang ditetapkan.

Dengan penerapkan aturan tata 
tertib tersebut perusahaan berkomitmen untuk meraih kinerja yang baik. Kinerja perusahaan dinilai berdasarakan kemampuan manajemen mempertanggungjawabkan segala kegaitannya kepada shareholdernya melalui praktik Good Corporate Governance (GCG). Penilaian kinerja perusahaan dalam melaksanakan praktik Good Corporate Governance, dilakukan assessment di tahun 2014 oleh BPKP selaku auditor independen dengan hasil score sebesar 76 atau dengan predikat baik. Sementara tingkat kesehatan perusahaan diukur berdasarkan Keputusan Menteri BUMN KEP-100/MBU/2002 oleh BPKP memperoleh skor senilai 96 atau perusahaan termasuk dalam kategori sehat (Annual Report PT. TWC, 2014).

\section{Strategi Pemasaran PT. Taman Wisata Candi}

Strategi pemasaran PT. Taman Wisata Candi diterapkan untuk mendapatkan positioning yang baik didalam pasar. Strategi pemasaran yang dikembangkan perusahaan selama tahun 2014 dalam laporan annual report perusahaan adalah dengan melakukan diversifikasi pemasaran dalam bentuk :

a. Peningkatan Penetrasi Pasar

Dengan strategi pemasaran ini PT. Taman Wisata Candi Borobudur, Prambanan \& Ratu Boko, berupaya melakukan kegiatan pengenalan (Brand Awareness) dan membangun relasi (Building Relationship) maupun kegiatan lainnya, seperti menjadi host dalam berbagai event seminar, pertemuan, olahraga, promosi (pemasangan) iklan baik secara nasional maupun internasional yang bertujuan untuk lebih memperkenalkan terhadap destinasi wisata budaya yaitu Candi Borobudur, Candi Prambanan \& Keraton Ratu Boko sebagai destinasi yang aman, nyaman dan ramah lingkungan kepada pasar (calon pengunjung).

b. Pengembangan Pasar Mancanegara
Strategi pemasaran untuk promosi wisatawan mancanegara dilakukan PT. Taman Wisata Candi melalui keikutsertaan dalam berbagai event kegiatan internasional antara lain :

1.) International Exibition \& Sales Mission:

Kegiatan pemasaran untuk memperkenalkan wisata budaya candi Borobudur, Prambanan dan Ratu Boko kepada pasar mancanegara dengan cara mengikuti berbagai event sepeti Malaysian Assosiation of Tour \& Travel Agent (MATTA) Fair 2014 di Kuala Lumpur, B2B dan B2C; mengikuti event NATAS Fair di Singapura; mengikuti kegiatan ITB Berlin dan Audensi dengan Duta Besar RI di Belanda, Jerman \& Spanyol; mengikuti Hana Tour International Travel Show di Seoul Korea Selatan; Direktur Pemasaran PT. TWC diundang sebagai pembicara utama mewakili Indonesia pada International Heritage Conference di Museum Vatikan pada tanggal 18 November 2014; mengikuti kegiatan 20th ODDYKH Leisure Moscow; mengikuti pameran JATA Tabihaku Travel Showcase 23-29 September 2014; taipei International Travel Fair dan ITB Asia Singapore, 29-31 Oktober 2014.

2.) Joint Promotion

Penerapkan strategi pemasaran ini digunakan untuk meningkatkan pengenalan wisata candi kepada pasar mancanegara bekerjasama dengan institusi domestik dan asing antara lain melalui : majalah Thomas Cook German yang memuat artikel Candi Borobudur dan Candi Prambanan tahun 2014-2015; kampanye pemasaran dengan FTI Thudstik Jerman; Deva Group untuk kegiatan Serbia Beograd Travel Mart 2014; Perusahaan TUI Germany 
untuk tahun 2014-2015; Perusahaan KRANS NL Nederland untuk tahun 2014-2015; Catalog brosur Tourasia Switzerland tahun 20142015; Perusahaan KUONI Nederland untuk tahun 2014; Kedutaan RI Belanda di trem Belanda dengan memasang iklan Candi Borobudur di Trem Rotterdam, serta menempatkan materi promosi Candi Borobudur, Prambanan \& Ratu Boko di salah satu tempat pengurusan Visa; Joint promotion dengan Lemhanas dengan mengadakan presentasi oleh Direktur Pemasaran didepan para Duta Besar yang menjadi target penetrasi pasar seperti: Perancis, Rusia dan Duta Besar Italia dalam bentuk jamuan makan malam di Lemhanas Jakarta, untuk masing-masing duta besar beserta jajaran atasenya pada waktu yang berbeda-beda; FOX Vakanties tahun 2014; Bali Rasa Sayang di manual Booklet 2014; Kanku Tabihaku di Jepang; dan melalui Keanggotaan PATA 2014-2015

c. Peningkatan Awareness Pasar Dalam Negeri

Kegiatan promosi pariwisata dalam negeri untuk wisatawan nusantara dan pelajar-mahasiswa dilakukan untuk meningkatkan daya ingat konsumen terhadap taman wisata candi yang ada di Yogyakarta dengan mengadakan kegiatan kepariwisataan. Kegiatan ini bekerjasama dengan para pelaku pariwisata Daerah Istimewa Yogyakarta, antara lain dengan Dinas Pariwisata DIY, Dinas Pariwisata Sleman, Kementerian Pendidikan dan Kebudayaan (Direktorat Jenderal Sejarah dan Purbakala), ASITA, PHRI dan HPI, BPPS dan BP2KY. Kegiatan promosi untuk meningkatkan awareness pasar dalam negeri yang dilakukan selama tahun 2014 antara lain meliputi:

1.) Promosi bersama dengan para pelaku pariwisata Daerah Istimewa Yogyakarta

Dalam rangka mempromosikan Yogyakarta antara lain dengan Dinas Pariwisata DIY, Dinas Pariwisata Sleman, dan ASITA yaitu : travel dialog bersama Dinas Pariwisata Sleman ke Grobogan dan Kudus; ASITA Table Top di Bali bersama ASITA DIY dan salles call dengan travel di Bali; Travel dialog bersama Dinas Provinsi DIY ke Purwokerto dan Banjar; Travel dialog dengan Unit Borobudur se Kabupaten Tegal, Cirebon, dan Pekalongan; Travel dialog bersama Dinas Pariwisata Sleman ke Bali pada tanggal 26-29 Agustus 2014 dengan kepala sekolah SMP/ SMA; travel dialog bersama Dinas Pariwisata Kabupaten Gunung Kidul ke Kediri pada tanggal 23-24 September 2014 dengan kepala sekolah SMP/SMA dan Travel Agent; Travel dialog bersama Java Promo ke Bangka Belitung pada tanggal 20 September - 02 Oktober 2014 dengan Travel Agent dan pelaku pariwisata; Mengikuti ASITA Travel Fair di Semarang dan Promosi masa ramai Lebaran Idul Fitri $1435 \mathrm{H}$.

2.) Pemasangan iklan di Media Cetak : Iklan menjadi sarana yang tidak kalah penting dalam promosi wisata candi karena iklan dapat dibuat dengan cara informatif yang memuat teks dan gambar sehingga mudah diingat calon pengunjung. Pemasangan iklan PT. TWC diterapkan antara lain pada Buku Directory Pariwisata DIY; Iklan Majalah In-Fight Garuda Indonesia; Pemasangan iklan Ucapan Ulang Tahun Inna Garuda di Radar Solo Pos Group pada tanggal 26 Juli 2014; Iklan kolektif ucapan ulang tahun Monumen Jogya Kembali tanggal 06 Juli 2014; Pemasangan iklan 
Sendratari Mahakarya Borobudur di Majalah Sabana dan Iklan di Tabloid Info Wisata Sendratari Mahakarya Borobudur.

3.) Sponsorship

Kegiatan sponsorship dilaksanakan untuk lebih mengenalkan taman wisata candi kepada masyarakat. Sifatnya yang temporer menjadi satu kelemahan sehingga perusahaan harus mengoptimalkan kegiatan ini dengan memilih menjadi sponsor untuk kegiatan yang masih berhubungan dengan kepariwisataan. Upaya PT. TWC untuk menjadi sponsor antara lain diterapkan pada acara-acara (event) antara lain : Sponsorship HUT PHRI, Harian Radar Yogya, AAU buku profil, HUT Lemhanas, dan UGM Catalonia Model United Nations; Sponsorship Harian Harmoni, penerbitan buku 150 tahun Prangko Indonesia, Pemi- lihan Duta Wisata Kabupaten Magelang, pembuatan DVD Provile Pariwisata Kabu- paten Magelang, Kirab Budaya Dinas Pari-wisata Klaten, penyelenggaraan Putra Putri Batik Nusantara, penerbitan buku Jogja Tourist Directory, kegiatan DMO Borobudur, pemilihan Mas dan Mbak Dita Wisata Klaten 2014, dan Pentas Seni Budaya Nusantara SD Islam At Taqwa; Kegiatan Jateng Fair di Semarang; dan Pameran Market Exhibition di Bali tanggal 27-30 Agustus 2014

4.) Penyelenggaran Event $200 \mathrm{Th}$ Penemuan Candi Borobudur

Penyelenggaraan event selain bekerjasama dengan pihak lain juga digagas sendiri oleh manajemen PT. TWC. Event yang diselenggarakan ini antara lain : seminar "Membangun Ketahanan Budaya \& Pariwisata, untuk Memperkokoh Ketahanan Nasional" oleh Bapak Prof. Dr.
Ir. Budi Susilo Soepandji, DEA (Gubernur Lemhanas), Bapak Dr. Kacung Marijan (Direktur Jenderal Kebudayaan), Bapak DR. Hari Untoro Dradjat (Staf Ahli kementerian \& Ekonomi Kreatif), Bapak Prof. Dr. Anhar Gonggong, M.Pd (Tenaga Profesional LEMHANAS RI) Bapak I Gede Ardhika (Mantan Menteri Pariwisata RI) serta Bapak Emha Ainun Najib (Budayawan) pada tanggal 22 Agustus 2014 di Semanggi Grand Ballroom, Grand Artos Hotel Magelang; Sendratari Mahakarya Borobudur, pada tanggal 23 Agustus 2014; Borobudur Fun Bike, dengan tema Fun Bike 200 tahun ditemukannya Candi Borobudur pada tanggal 12 Oktober 2014; Pemecahan Record Dunia RHR \& MURI oleh Harry Wisnu pada tangga 14 November 2014, memainkan 300 buah lagu jazz dengan 13 jenis alat music tiup; Puncak Acara Peringatan 200 Th Penemuan Candi Borobudur pada tanggal 15 November 2015 dengan Peluncuran Perangko seri 200 Tahun Borobudur oleh Menteri Koordinator Bidang Pembangunan Manusia dan Kebudayaan RI, Menteri Pemuda \& Olah Raga, Duta Besar Inggris untuk Indonesia serta didampingi oleh Gubernur Jawa Tengah; Pemecahan 2 buah rekor dunia meniup 13 jenis alat musik tiup dengan 300 lagu jazz oleh Mr. Harry Wisnu, pada tanggal 15 November 2014 di Borobudur; Borobudur Writer \& Cultural Festival pada tanggal $13-15$ November 2014; Borobudur $10 \mathrm{~K}$, pada tanggal 16 November 2014 bekerjasama dengan Dinas Pariwisata Jawa Tengah; TWC Customer Award 2014 dengan "Partnership In Harmony" pada tanggal 29 Desember 2014 bertempat di Plaza Andrawina keratin Ratu Boko; Borobudur Musik \& Lampion Festival 2014, pertunjukan 
musik oleh Hari Wisnu dan pelepasan lampion 2015 buah terse-bar di 20 desa sekitar candi Borobudur; dan Pembuatan film 200 tahun penemuan candi Borobudur;

5.) Pengadaan Dan Penyusunan Materi Promosi

Materi promosi diperlukan untuk mengakomodasi segala kebutuhan informasi dalam meningkatkan pemahaman akan keberadaan candi Borobudur, Prambanan dan Ratu Boko yang dikelola PT. Taman Wisata Candi. Materi promosi yang disiapkan antara lain : pengadaan materi promosi brosur terpadu Kantor Pusat; Penyusunan Corporate Branding untuk lima tahun ke depan dalam sebuah Marketing Masterplan; Pengadaan sticker cutting Taman Wisata; Pemesanan Billboard di tiga titik daerah Yogyakarta; Pembuatan film 200 tahun penemuan candi Borobudur; dan Pembelian perangko Keraton Ratu Boko

f. Pengembangan Jasa Dan Produk Pariwisata Baru

Kegiatan pengembangan jasa dan produk baru dilakukan dalam rangka meningkatkan prestasi bisnis perusahaan dalam menghasilkan keuntungan. Pengembangan produk baru oleh perusahaan dimaksimalkan dengan adanya penelitian-penelitian terkait dengan usaha jasa wisata khususnya yang dikelola PT. Taman Wisata Candi. Pengembangan jasa pariwisata baru oleh perusahaan dilakukan untuk beberapa hal antaralain:pembuatandanpenerbitanbuku situs Ratu Boko, pengimplementasian dan pengembangan sistem e-ticketing, perbaikan company web bekerjasama dengan telkom, pembangunan plasa unit candi Borobudur, pembenahan dan pembersihan lahan untuk camping di unit situs keraton Ratu Boko.

\section{Analisis Implementasi Strategi dan Pencapaian}

Dalam rangka mewujudan salah satu misi perusahaan yaitu meningkatkan nilai perusahaan yang berkelanjutan, maka dibutuhkan penyusunan rencana strategis untuk setiap unit kerja sebagai landasan (acuan) dalam melaksanakan tugas dan kewajibannya. Dari aspek pemasaran PT. Taman Wisata Candi menerapkan strategi pemasaran di tahun 2014 yang berkonsentrasi pada efisiensi biaya namun dengan dampak yang maksimal pada hasil pemasaran (low cost high impact). Secara jelas implementasi pemasaran yang dilakukan PT. TWC dapat diringkas menjadi gambar sebagai berikut : 


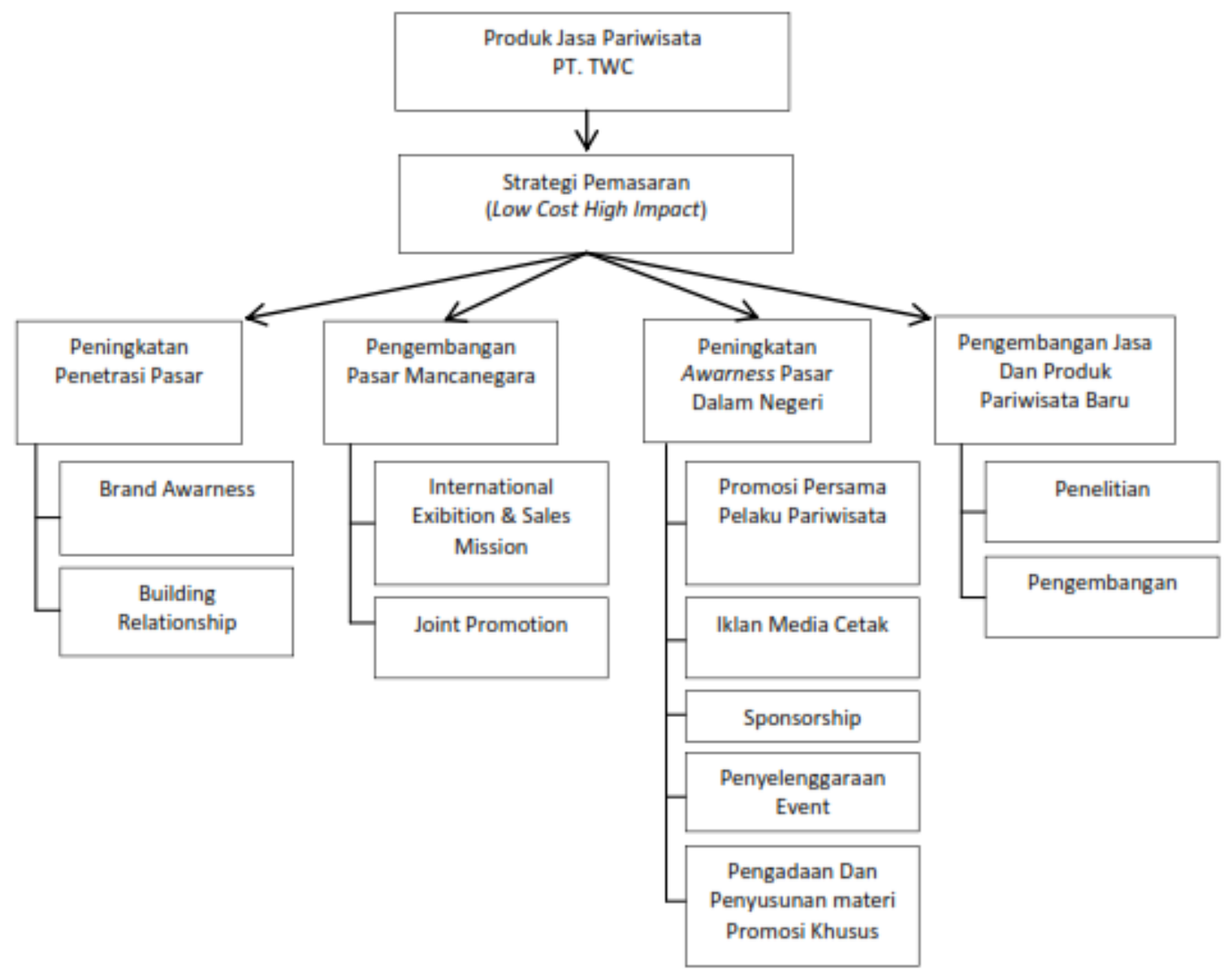

Sumber : Annual Report PT. TWC 2014 (diolah)

Gambar 1. Implementasi Strategi Pemasaran PT. TWC

Gambar 1 menunjukkan strategi pemasaran yang telah dilaksanakan perusahaan pada tahun 2014. Ukuran keberhasilan (capaian) perusahaan dalam mewujudkan salah satu misinya yaitu meningkatkan nilai perusahaan berkelanjutan adalah dengan mengukur keberhasilan implementasi strategi pemasaran perusahaan dalam meningkatkan

jumlah pengunjung yang datang dan laba yang dihasilkan dari tahun ke tahun.

Data annual report tahun 2014 secara jelas menunjukkan keberhasilan perusahaan dalam meningkatkan jumlah pengunjung candi Borobudur, Prambanan dan Ratu Boko yang dikelola PT. Taman Wisata Candi sebagai berikut :

Tabel 1. Jumlah Pengunjung Candi Borobudur, Prambanan Dan Ratu Boko

\begin{tabular}{|l|r|r|r|r|r|}
\hline \multirow{2}{*}{ Keterangan } & \multicolumn{5}{|c|}{ Tahun } \\
\cline { 2 - 6 } & 2010 & 2011 & 2012 & \multicolumn{1}{|c|}{2013} & \multicolumn{1}{|c|}{2014} \\
\hline wisman & 291.298 & 315.279 & 366.003 & 430.275 & 593.643 \\
\hline wisnus & 3.338 .788 & 3.068 .952 & 4.046 .579 & 4.534 .161 & 4.661 .466 \\
\hline Jumlah & 3.630 .086 & 3.384 .231 & 4.412 .582 & 4.964 .436 & 5.255 .109 \\
\hline
\end{tabular}

Sumber : Annual Report PT. TWC 2014 (diolah) 
Berdasarkan data tabel 1. menjelaskan bahwa telah terjadi peningkatan jumlah pengunjung sejak tahun 2012. Implementasi strategi pemasaran ditahun 2014 berhasil meningkatkan jumlah pengunjung dari 4.964.436 orang pada tahun 2013 menjadi 5.255.109 orang pengunjung ditahun 2014 (naik 2,8\%). Grafik berikut ini menggambarkan peningkatan jumlah pengunjung taman wisata candi Borobudur, Prambanan dan Ratu Boko secara komulatif.

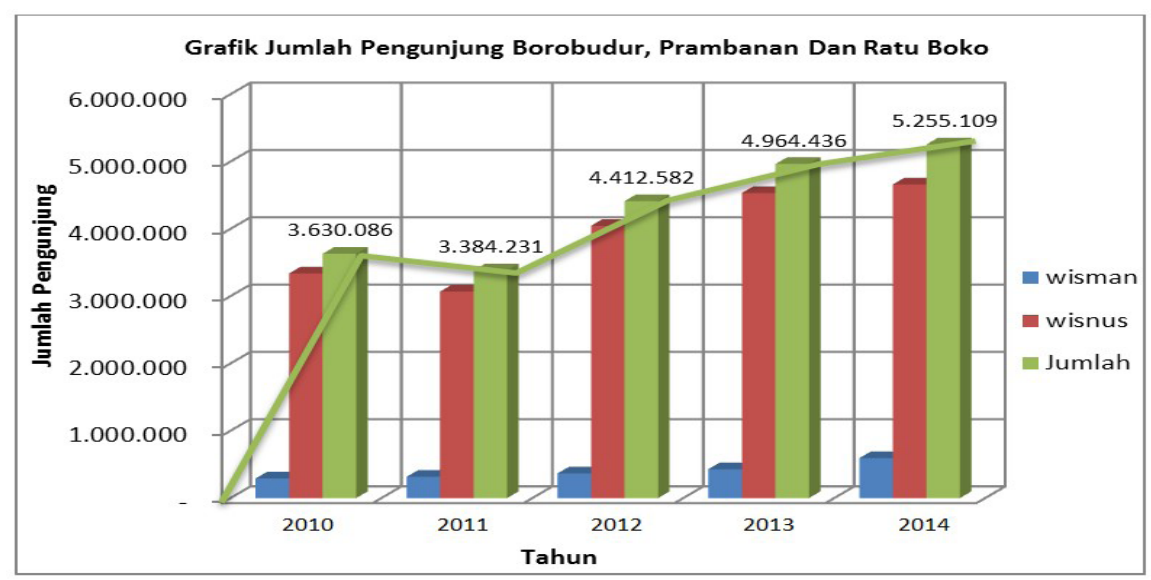

Sumber : Annual Report PT. TWC 2014 (diolah)

Gambar 2. Grafik Jumlah Pengunjung

Kondisi ini mengindikasikan bahwa implementasi strategi pemasaran yang diterapkan perusahaan telah berhasil dalam meningkatkan jumlah pengunjung. Empat strategi pemasaran yang diimplementasikan PT. TWC yaitu peningkatan penetrasi pasar domestik dan mancanegara, pengembangan pasar mancanegara, peningkatan awerness pasar dalam negeri, pengembangan jasa dan penciptaan produk pariwisata baru. Jadi berdasar data dan fakta tersebut dapat disimpulkan bahwa implementasi strategi pemasaran PT. Taman Wisata Candi sukses dalam meningkatkan jumlah kunjungan wisatawan baik domestik maupun mancanegara.

Dari aspek efisiensi biaya sesuai dengan strategi low cost hight impact yang diterapkan perusahaan dapat dianalisis, bahwa dampak strategi marketing cukup baik namun jika melihat pos biaya yang dikeluarkan ditahun 2014 satu diantaranya justru menunjukkan adanya kenaikan. Kondisi ini dapat diperjelas dengan datadata laporan rugi-laba perusahaan sebagai berikut :

Tabel 2. Laporan Rugi/Laba Perusahaan (million)

PROFIT \& LOSS

\begin{tabular}{rrrrrrr} 
& 2010 & 2011 & 2012 & 2013 & 2014 \\
\hline Pendapatan Operasional & 103.135 & 111.135 & 167.462 & 209.649 & 235.349 \\
\hline Biaya Langsung & 19.823 & 22.541 & 27.262 & 36.715 & 99.080 \\
\hline Biaya Tidak Langsung & 58.373 & 61.417 & 88.909 & 105.558 & 86.318 \\
\hline Biaya \& Pendapatan Non Ops. & $(1.185)$ & $(1.128)$ & $(261)$ & $(14.504)$ & 5.957 \\
\hline Laba Rugi Sebelum Pajak & 17.304 & 18.818 & 39.513 & 10.462 & 55.909 \\
\hline Laba setelah Pajak & 12.826 & 13.817 & 29.132 & 34.728 & 42.808 \\
\hline
\end{tabular}

Sumber : Annual Report PT. TWC (2014:7) 
Terlihat dalam tabel 2. keinginan perusahaan dalam menekan biaya operasi melalui prinsip low cost belum memberikan dampak bagi penurunan khususnya pos biaya langsung yang ditahun 2014 mengalami kenaikan dua kali lebih besar yaitu 45,9\% atau sebesar Rp. 99.080 milliar dibanding tahun sebelumnya. Dari sudut kemampuan perusahaan dalam menghasilkan laba tidak dipungkiri bahwa perusahaan berhasil meningkatkan kinerjanya dengan wujud laba usaha dengan kenaikan 10,4\% atau sebesar 42.808 milliar seiring keberhasilan strategi pemasaran yang diimplementasikan untuk periode tahun 2014.
Dampak yang cukup signifikan dalam penerapan strategi pemasaran low cost high impact selain kenaikan jumlah pengunjung dan laba perusahaan adalah kenaikan jumlah pos laba ditahan dan modal serta penurunan pertumbuhan hutang sebesar $7,9 \%$ ditahun 2014. Namun demikian penurunan rasio lancar perusahaan sebagai akibat kenaikan biaya langsung dan pelunasan hutang perlu diwaspadai untuk mengantisipasi perusahaan.

Tabel 3. Laporan Ringkas Pertumbuhan Keuangan PT. TWC

\begin{tabular}{rrrrrrr} 
& \multicolumn{2}{c}{2010} & 2011 & 2012 & 2013 & 2014 \\
\hline Aset Lancar & 44.918 .138 .329 & 50.918 .190 .070 & 78.284 .349 .974 & 110.696 .552 .261 & 139.500 .983 .558 \\
\hline Liabilitas Jangka Pendek & 18.751 .790 .609 & 20.720 .783 .255 & 37.111 .567 .553 & 38.680 .136 .814 & 54.270 .626 .448 \\
\hline Liabilitas Lain-lain & 3.772 .441 .000 & 4.443 .911 .548 & 4.191 .266 .904 & 29.003 .489 .155 & 18.738 .944 .767 \\
\hline Ekuitas & 78.377 .236 .181 & 78.377 .236 .180 & 100.105 .500 .000 & 100.105 .500 .000 & 100.105 .500 .000 \\
\hline Laba Ditahan & 47.061 .363 .081 & 60.364 .555 .465 & 67.215 .632 .635 & 84.998 .984 .993 & 125.308 .691 .394 \\
\hline TOTAL LABILITY \& EQuITY & 147.962 .830 .871 & 163.906 .486 .448 & 208.623 .967 .092 & 252.788 .110 .962 & 298.424 .762 .609 \\
\hline Liability Growth & 42,9 & 11,7 & 64,1 & 63,9 & 7,9 \\
\hline Equity Growth & 10,8 & 10,6 & 20,6 & 10,6 & 21,8 \\
\hline Total Passiva Growth & 14,7 & 10,8 & 27,3 & 21,2 & 18,1 \\
\hline \hline Rasio Lancar & $239,54 \%$ & $245,73 \%$ & $212,40 \%$ & $294,24 \%$ & $257 \%$ \\
\hline
\end{tabular}

Sumber : Annual Report PT. TWC (2014:6-7) diolah

Jadi sesuai data pada tahun 2014, dari sisi kinerja keuangan perusahaan dapat ditarik kesimpulan bahwa implementasi strategi pemasaran low cost high impact berdampak besar pada kenaikan kemampuan perusahaan dalam menghasilkan laba usaha, pertumbuhan modal (laba ditahan), dan penurunan pertumbuhan total hutang khususnya melalui pos hutang lain-lain.

\section{KESIMPULAN}

Kesimpulan yang dapat diambil dari analisis implementasi strategi pemasaran PT. Taman Wisata Candi dalam meningkatkan jumlah pengunjung dan laba perusahaan adalah sebagai berikut :

1. Implementasi strategi pemasaran low cost high impact yang diterapkan perusahaan ditahun 2014 melalui peningkatan penetrasi pasar domestik dan mancanegara, pengembangan pasar mancanegara, peningkatan awerness pasar dalam negeri, pengembangan jasa dan penciptaan produk pariwisata baru membawa hasil dengan peningkatan jumlah pengunjung 2,8\% dan laba usaha $10,4 \%$ dari tahun sebelumnya.

2. Komitmen perusahaan dalam menerapkan strategi pemasaran dengan efisiensi biaya (low cost) di tahun 2014 belum memperoleh hasilyang maksimal sebab kenaikan pos biaya langsung $45,9 \%$ tidak signifikan dengan kenaikan laba usaha perusahaan 10,4\%. Dalam hal ini kenaikan biaya operasi langsung lebih 
besar dari pada kenaikan jumlah laba usaha perusahaan yang diikuti juga dengan penurunan likuiditas perusahaan dengan rasio lancar lebih kecil dibanding tahun sebelumnya.

\section{DAFTAR PUSTAKA}

Alma, Buchari. 2011. Manajemen Pemasaran Dan Pemasaran Jasa. Bandung : Alfabeta

Dumarcay, Jacques. 2007. Candi Sewu Dan Arsitektur Dan Bangunan Agama Budha Di jawa Tengah, Terjemahan : Winarsih Arifin Dan Henri Chambert- Loir. Jakarta : KPG (Kepustakaan Populer Gramedia).

http://borobudurpark.com/corporate/ node $/ 40$

http://internal.borobudurpark.co.id/ corporate/file2/Annual\%20Report $\% 20$ 2014.zip

Lupiyoadi, Rambat dan Hamdani, A., 2008. Manajemen Pemasaran Jasa. Jakarta : Salemba Empat

Rai, I Gusti Agung. 2008. Audit Kinerja Pada Sektor Publik : Konsep, Praktik Dan Studi kasus. Jakarta ; Salemba Empat

Rudianto. 2005. Akuntansi Manajemen : Informasi Untuk Pengambilan Keputusan Manajemen. Jakarta : Grasindo

Wendoris, Thomas. 2008. Mengenal Candicandi Nusantara. Yogyakarta : Pustaka Widyatama 